\title{
ANALISIS SELF CONFIDENCE SISWA KELAS X HT 3 SMK SANGKURIANG 2 DALAM PEMBELAJARAN MATEMATIKA
}

\author{
Ani Ainun Masruroh ${ }^{1}$, Yusuf Faturohman ${ }^{2}$, Wahyu Hidayat ${ }^{3}$, Euis Eti Rohaeti ${ }^{4}$ \\ 1,2,3 IKIP Siliwangi J1. Jenderal Sudirman, Cimahi Jawa Barat Indonesia \\ ${ }^{1}$ aniainun20@gmail.com,2 yusuffathurohman219@gmail. \\ Diterima: XXXXX X, XXXX; Disetujui: XXXXX X, XXXX
}

\begin{abstract}
SMA/SMK is the last high school before college.High School/SMK students are at a teenage stage which often has problems because of their personal and yet mature forms. That attitude affects the level of confidence such as fearless try and sometimes minder with self-thought. This research is done to know how much confidence that is owned by students in class X HT 3 SMK Sangkuriang 2 Cimahi, with the method used in the form of instrument confidence attitude.The instrument used includes 5 indicators including believing in self-ability, acting independently in making decisions, appreciating themselves and striving for themselves, eager to brainstorm and dare to face challenges.Based on research it is gained that students ' confident level is high enough and has great courage in the face of every challenge.
\end{abstract}

Keywords: Mathematical learning, self confidence, student

\begin{abstract}
Abstrak
SMA/SMK merupakan sekolah menengah terakhir sebelum ke perguruan tinggi. Siswa SMA/SMK berada pada tahap remaja yang mana sering mengalami permasalahan karena pribadinya yang masih labil dan belum terbentuk secara matang. Sikap labil itu mempengaruhi tingkat kepercayaan diri seperti tak kenal takut mencoba dan adakalanya minder dengan pemikiran sendiri. Penelitian ini dilakukan untuk mengetahui seberapa besar rasa percaya diri yang dimiliki oleh siswa di kelas X HT 3 SMK Sangkuriang 2 Cimahi, dengan metode yang digunakan berupa instrumen sikap kepercayaan diri. instrumen yang digunakan mencakup 5 indikator diantaranya percaya pada kemampuan diri sendiri, bertindak mandiri dalam mengambil keputusan, menghargai diri dan usaha sendiri, bersemangat ketika mengemukakan pendapat dan berani menghadapi tantangan. Berdasarkan penelitian di peroleh bahwa tingkat percaya diri siswa cukup tinggi dan memiliki keberanian yang besar dalam menghadapi setiap tantangan.
\end{abstract}

Kata Kunci: Pembelajaran Matematika, Percaya diri, Siswa

How to cite: Masruroh, A. A, Faturohman, Y., Hidayat, W., Rohaeti, E. E. (2019). Analisis Self Confidence Siswa Kelas X HT 3 SMK Sangkuriang 2 dalam Pembelajaran Matematika. JPMI - Jurnal Pembelajaran Matematika Inovatif, 2 (6), 379-384.

\section{PENDAHULUAN}

Siswa/siswi merupakan istilah bagi peserta didik di setiap jenjang pendidikan. Siswa adalah komponen masukan dalam sistem pendidikan, yang selanjutnya diproses dalam proses pendidikan, sehingga menjadi manusia yang berkualitas sesuai dengan tujuan pendidikan nasional. Menurut (UU RI No. 20 Tahun 2003 pasal 1 ayat 4, 2003) tentang sistem pendidikan nasional menyebutkan "Peserta didik adalah anggota masyarakat yang berusaha mengembangkan dirinya melalui proses pendidikan pada jalur jenjang dan jenis pendidikan tertentu”. Adapun Abu Achmadi salah satu pemerhati pendidikan mengungkapkan bahwa peserta didik atau siswa merupakan individu yang belum bisa dikatakan dewasa. Ia memerlukan usaha, bantuan, serta bimbingan dari seseorang untuk mencapai tingkat kedewasaannya. 
Sesuai dengan pengertian tersebut, cara siswa untuk meningkatkan kedewasaanya atau menjadi manusia yang berkualitas salah satunya dengan belajar. Belajar memiliki arti proses aktualisasi diri, dengan belajar siswa akan mendapatkan hal-ha baru yang nantinya akan menuntun menjadi seseorang yang berkualitas. Belajar saat ini seperti kita ketahui berpusat pada siswa. Maka dari itu siswa dituntut berperan aktif dalam kegiatan belajar mengajar. Untuk dapat aktif maka siswa harus memiliki rasa percaya diri. Percaya diri atau self confidence adalah sikap positif seorang individu yang merasa memiliki kompetensi atau kemampuan untuk membaggakan dirinya maupun lingkungan. self confidence adalah percaya akan kaemampuan sendiri yang memadai dan menyadari kemampuan yang dimiliki serta dapat dimanfaatkan secara tepat. Menurut hakim (2002) percaya diri tidak muncul begitu saja pada diri seseorang. Terdapat proses tertentu dalam pribadinya sehingga terjadilah pembentukan rasa percaya diri. Secara garis besar terbentuknya rasa percaya diri yang kuat pada seseorang terjadi melalui empat proses anatara lain:

1. Terbentuknya kepribadian yang baik sesuai dengan proses perkembangan yang melahirkan kelebihan-kelebihan tertentu

2. Pemahaman seseorang terhadap kelebihan-kelebihan yang dimilikinya yang melahirkan keyakinan kuat untuk bisa berbuat segala sesuatu dengan memanfaatkan kelebihankelebihannya.

3. Pemahaman dan reaksi-reaksi positif seseorang terhadap kelemahan-kelemahan yang dimilikinya agar tidak menimbulkan rasa rendah diri atau rasa sulit menyesuaikan diri.

4. Pengalaman dalam menjalani berbagai aspek kehidupan dengan menggunakan segala kelebihan yang ada pada dirinya.

Pemaparan tersebut menyatakan bahwa self confidence bukan merupakan sifat bawaan namun merupakan sesuatu yang terbentuk dari interaksi. Rasa percaya diri harus selalu diterapkan dalam setiap pembelajaran termasuk matematika. Sebagaimana kita ketahui matematika merupakan salah satu ilmu pengetahuan yang selalu digunakan dalam kehidupan sehari-hari. Standar isi untuk satuan pendidikan dasar dan menengah mata pelajaran matematika (Sudrajat, 2009) tentang itandar isi menyebutkan bahwa salah satu tujuan pembelajaran matematika adalah supaya siswa memiliki kemampuan mengkomunikasikan gagasan dengan simbol, tabel, diagram, atau media lain untuk memperjelas keadaaan atau masalah. Dari pengertian tersebut, tersirat jelas bahwa kepercayaan diri sangatlah penting dalam pembelajaran matematika, karena dalam mengkomunikasikan matematika harus memiliki rasa percaya diri terlebih dahulu.

Mengingat pentingnya memiliki rasa percaya diri, penelitian ini bermaksud melihat tingkat kepercayaan diri siswa di jenjang SMA/SMK.

\section{METODE}

Penelitian dilakukan menggunakan metode penelitian survei, (Triyono, 2013) metode penelitian survei sendiri yaitu metode untuk mendapatkan hasil dalam bentuk opini/pendapat dari orang yang berinteraksi langsung dengan apa yang diamati. Metode ini memiliki tujuan utama yakni mengetahui gambaran umum melalui sampel beberapa orang. Sesuai dengan pengertian dari metode penelitian tersebut, kami melakukan seurvei untuk mengetahui tingkat kepercayaan diri siswa terhadap pelajaran matematika di kelas X HT 3 SMK 2 Sangkuriang Cimahi. Survei dilakukan dengan cara memberikan instrumen soal mengenai kepercayaan diri siswa terhadap pelajaran matematika. Instrumen tersebut terdiri dari lima indikator kepercayaan diri, yaitu percaya pada kemampuan sendiri, bertindak mandiri dalam mengambil keputusan, menghargai diri dan usaha sendiri, bersemangat ketika mengemukakan pendapat dalam diskusi dan berani menghadapi tantangan. Dalam penilainnya di dapat hasil tertinggi dari setiap indikator yang ada pada instrumen, proses tersebut di dapat dengan cara berikut: 
persentase butir soal $=\frac{\text { jumlah nilai }}{\text { jumlah keseluruhan soal } \times \text { nilai SMI } \times \text { jumlah siswa }} \times 100$

persentase indikator $=\frac{\text { jumlah nilai indikator }}{\text { jumlah keseluruhan nilai SMI } \times \text { jumlah siswa }} \times 100$

\section{HASIL DAN PEMBAHASAN}

Hasil

Angket self-confindence yang digunakan dalam penelitian ini terdiri dari 33 pernyataan, dimana angket tersebut dibuat ke dalam pernyataan positif dan pernyataan negatif. Angket ini terdiri dari 5 indikator kepercayaan diri. berikut hasil uji angket yang dilakukan terhadap siswa kelas X HT 3:

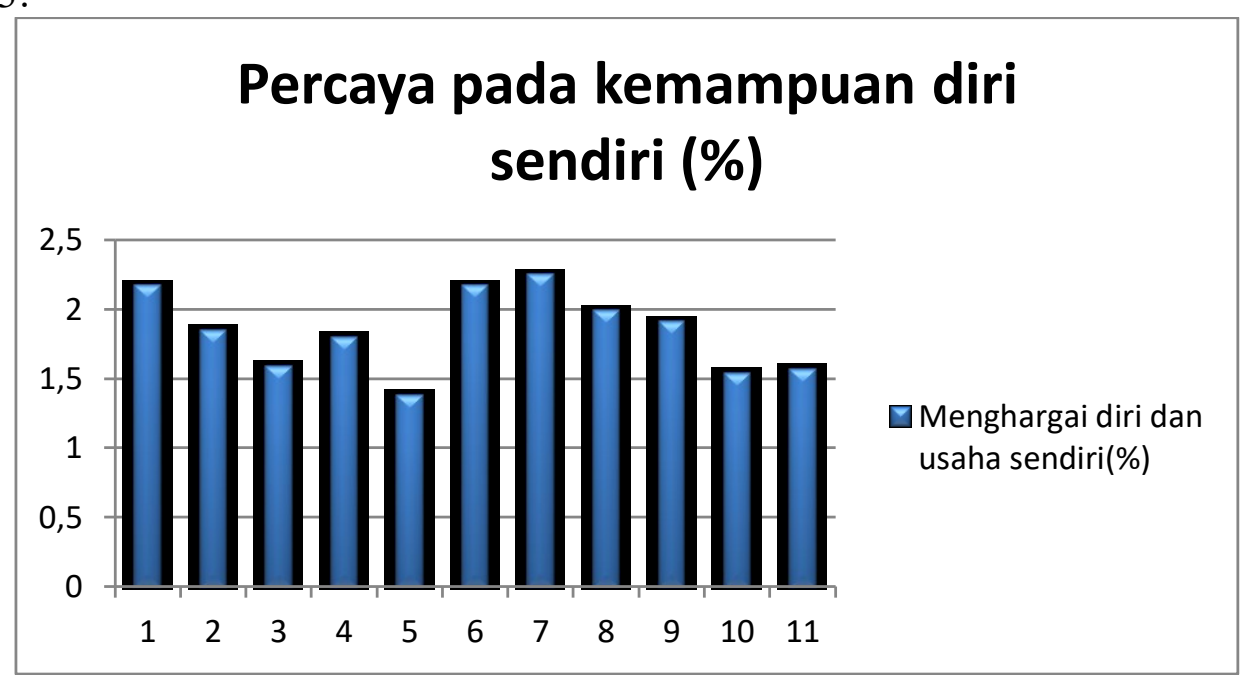

Grafik 1. Persentase indikator percaya pada kemampuan diri sendiri

Hasil uji angket yang dilakukan pada kelas X HT 3 di SMK 2 Sangkuriang pada indikator percaya pada kemapuan diri sendiri memiliki 11 soal. Diantara 11 soal tersebut persentase terendah terdapat pada soal ke 5 yang hanya mendapatkan $1,38 \%$ dan persentase tertinggi terdapat pada soal ke 7 yang mendapatkan $2,25 \%$.

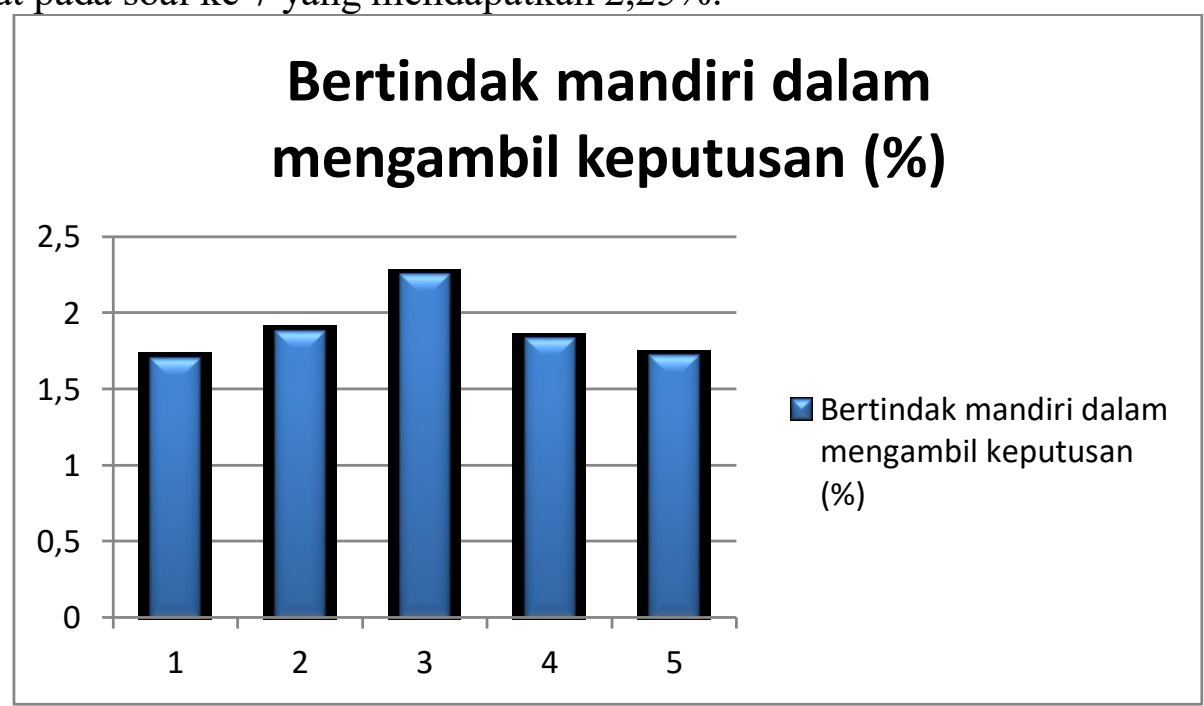

Grafik 2. Persentase indikator bertindak mandiri dalam mengambil keputusan 
Berdasarkan grafik diatas, untuk indikator bertindak mandiri dalam mengambil keputusan memiliki persentase tertinggi sebesar 2,25\% dari jumlah keseluruhan soal sebanyak 5 soal dan jumlah persentse sebesar $9,38 \%$.

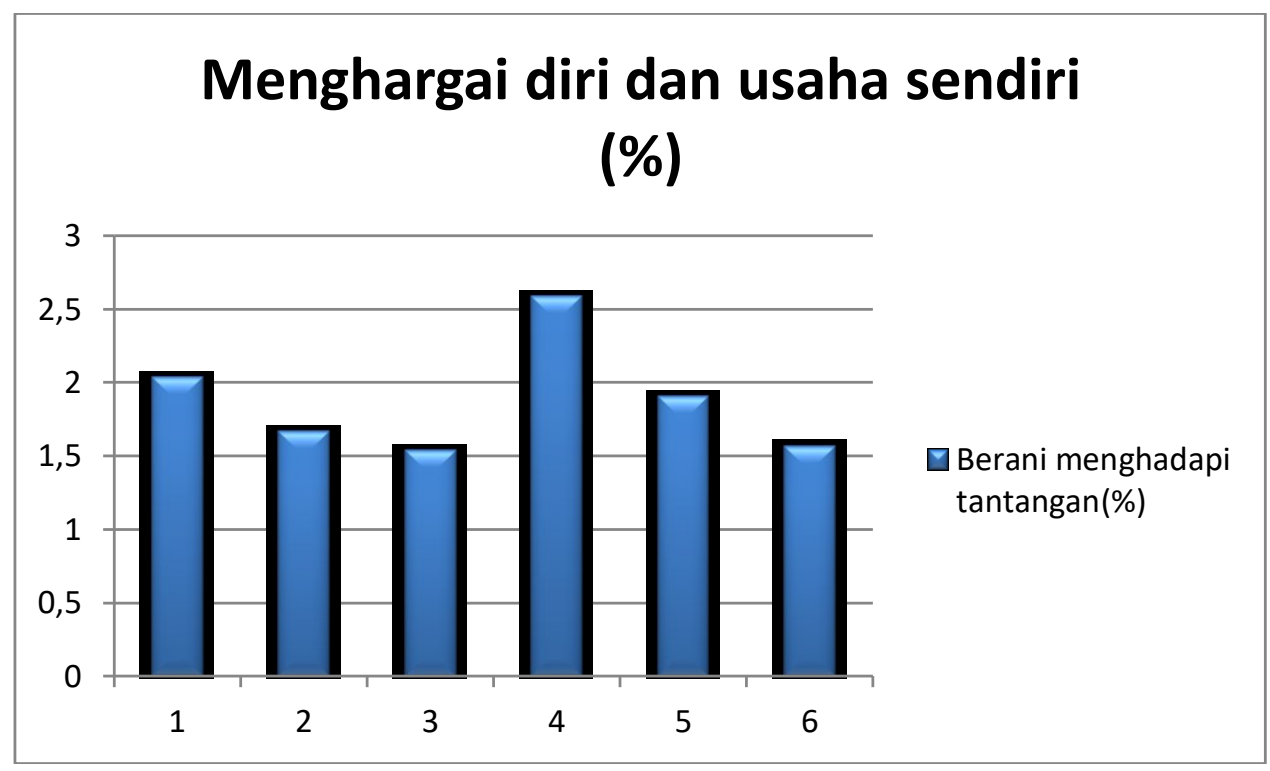

Grafik 3. Persentase indikator menghargai diri dan usaha sendiri

Untuk indikator menghargai diri dan usaha sendiri terdapat 6 soal dengan jumlah persentase sebesar $11.32 \%$ dan dari 6 soal tersebut yang memilii persentase terbesar terdapat pada soal nomor 4 dengan nilai persentase sebesar $2,59 \%$.

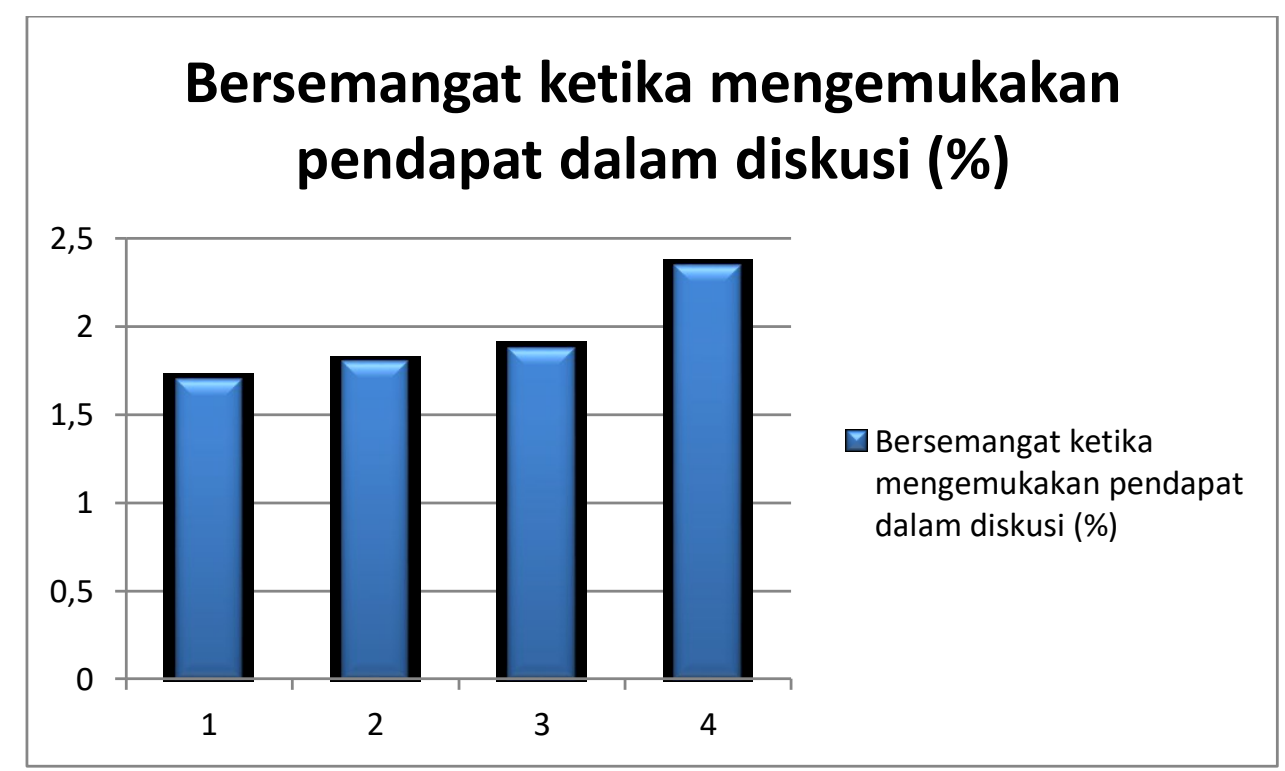

Grafik 4. Persentase indikator bersemangat ketika mengemukakan pendapat

Indikator ini terdiri dari 4 soal dan persentase yang didapatkan dari 29 siswa untuk indikator ini sebesar $7,73 \%$ dengan persentase terbesar terdapat pada soal keempat dengan nilai $2,35 \%$. 


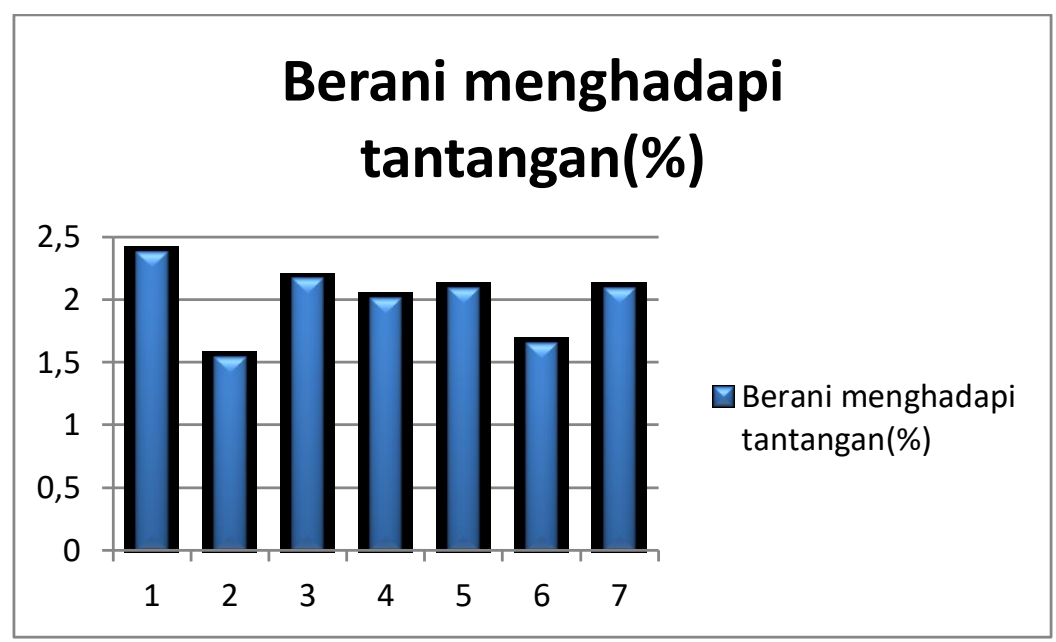

Grafik 5. Persentase indikator berani menghadapi tantangan

Dari grafik tersebut, diketahui bahwa siswa kelas X HT 3 memiliki tingkat keberanian yang tinggi dengan jumlah persentase sebesar $13,95 \%$ dan soal nomor satu memiliki persentase sebesar $2,38 \%$.

\section{Pembahasan}

Berdasarkan hasil penelitian yang telah dilakukan di dapat bahwa tingkat kepercayaan diri siswa kelas X HT 3 terhadap mata pelajaran matematika sebesar $62,52 \%$ dengan persentase setiap indikatornya secara berturut-turut yaitu $20,22 \% ; 9,38 \% ; 11,32 \% ; 7,73 \%$ dan $13,93 \%$, persentase tersebut cukup tinggi, tingginya rasa percaya diri akan berpengaruh terhadap prestasi belajar siswa, sebagaimana yang disampaikan komara (Sritresna, 2017) bahwa semakin tinggi kepercayaan diri dan prestasi belajar maka perencanaan karir semakin tinggi dan sebaliknya apabila kepercayaan diri dan prestasi belajar rendah maka perencanaan karir akan semakin rendah.

Hasil persentase setiap indikator terdapat nilai yang memiliki persentase paling besar dari setiap soal perindikatornya. Seperti halnya pada indikator percaya pada kemampuan diri sendiri, dari 11 soal yang ada pada indikator tersebut ditemukan bahwa soal nomor 7 memiliki nilai persentase terbesar yaitu $2,25 \%$ dengan bunyi pernyataannya yaitu "merasa gugup dalam menghadapi soal matematika" dari hasil tersebut dapat terlihat banwa masih banyak siswa yang merasa gugup akan dirinya sendiri ketika mengahadapi masalah-masalah matematika. Selanjutnya indikator bertindak mandiri dalam mengambil keputusan terdiri dari 5 soal dengan jumlah persentase sebesar $9,38 \%$ dan persentase terbesar terdapat pada soal nomor 3 dengan jumlah persentase sebesar 2,25\%. Bunyi pernyataan dari soal nomor 3 yaitu "berusaha keras memahami materi matematika pada umumnya". Dari persentase yang di dapat untuk pernyataan tersebut dapat kita ketahui bahwasannya siswa di kelas tersebut mempunyai keinginan yang besar untuk tidak menyerah tetapi memutuskan berusaha dengan keras meskipun materi matematika dirasa cukup sulit untuk dipahami.

Indikator ketiga yaitu menghargai diri dan usaha sendiri. dari 6 soal yang ada pada indikator ini didapat persentase hasil penelitian yang dilakukan sebesar $11.32 \%$ dengan tingkat persentase terbesar terdapat pada soal nomor 4 dengan persentase sebesar 2,59\%, bunyi dari pernyataan nomor 4 tersebut yaitu "bangga dengan hasil pekerjaan matematika sendiri". Maka dengan nilai persentase tersebut kita tahu bahwa siswa sangatlah menghargai apa yang telah mereka kerjakan, meskipun nilai yang didapatkan tidak sesuai dengan apa yang diharapkan. Indikator lainnya yaitu bersemangat ketika mengemukakan pendapat dalam diskusi. Dari angket yang 
telah disebar, didapat jumlah persentase sebesar $7,73 \%$ dari 4 pernyataan yang ada. Dan pernyataan yang memiliki nilai lebih besar pada indikator ini dengan nilai persentase sebesar $2,35 \%$ terdapat pada pernyataan nomor 4 yang berbunyi "menerima kritikan teman atas pekerjaan matematika yang sedang terbuka". Dilihat dari persentasenya, siswa kelas X HT 3 dapat menerima setiap krikitan yang disampaikan oleh temannya terhadap pekerjaan matematika yang sedang dikerjakan. Indikator terakhir yaitu berani menghadapi tantangan. Siswa SMA merupakan usia yang sedang menggebu-gebu, selalu tertantang akan sesuatu dan memiliki tingkat keberanian yang besar. Namun ternyata berbeda jika dihadapkan dengan persoalan matematika, dari hasil angket yang telah diisi, didapat persentase sebesar $13,93 \%$ yang terdiri dari 7 pernyataan, dengan persentase pernyataan terbesar ada pada pernyataan nomor satu yang menyebutkan "merasa ragu menghadapi ulangan matematika yang tiba-tiba" sebesar $2,38 \%$.

Hasil tersebut menyatakan bahwa setiap siswa pada usia remaja memiliki rasa percaya diri yang cukup tinggi. Kepercayaan diri siswa menjadi salah satu faktor yang akan mempengaruhi proses belajar siswa seperti yang disebutkan (Pratiwi \& Laksmiwati, 2016) bahwa kepercayaan diri siswa mempunyai peran yang sangat signifikan dalam kegiatan belajar. Jika siswa dalam belajar mempunyai kepercayaan diri yang tinggi maka hasil yang diperolehnya akan maksimal.

\section{KESIMPULAN}

Berdasarkan hasil penelitian yang dilakukan dapat disimpulkan bahwa kepercayaan diri siswa kelas X HT 3 SMK 2 Sangkuriang memiliki rasa percaya diri yang cukup tinggi dengan persentase keseluruhan $62,52 \%$ pada mata pelajaran matematika. Selain itu, dari hasil persentase dari ke 5 indikator didapat bahwa siswa kelas X HT 3 meskipun mata pelajaran matematika merupakan salah satu mata pelajaran yang sulit mereka berusaha dengan kemampuan mereka sendiri untuk bisa dalam pelajaran matematika.

\section{UCAPAN TERIMA KASIH}

Pelaksanaan penelitian ini tidak akan terlaksana tanpa adanya bantua dari berbagai pihak. Untuk itu saya ucapkan terimakasih banyak kepada:

1. IKIP Siliwangi selaku kampus selaku institusi yang menaungi kami.

2. Fakultas Pendidikan Matematika dan Sains

3. Program Studi Pendidikan Matematika.

4. Dr. Wahyu Hidayat. M.Pd. selaku dosen mata kuliah metode penelitian.

5. SMK Sankuriang 2 Cimahi yang telah mengizinkan kami melaksanakan penelitian.

6. Siswa kelas X HT 3 SMK Sangkurian 2 Cimahi.

\section{DAFTAR PUSTAKA}

Pratiwi, I. D., \& Laksmiwati, H. (2016). Kepercayaan Diri dan Kemandirian Belajar Pada Siswa SMA Negeri "X." Psikologi Teori Dan Terapan, 7 No. 1.

Sritresna, T. (2017). MENINGKATKAN KEMAMPUAN KOMUNIKASI MATEMATIS DAN SELFCONFIDENCE SISWA MELALUI MODEL PEMBELAJARAN CYCLE 7E. Mosharafa, 6 No. 3.

Sudrajat, A. (2009). Permendiknas no. 22 tahun 2006. In Wordpress. Retrieved from https://akhmadsudrajat.files.wordpress.com/2009/04/permendiknas-no-22-tahun2006.pdf

Triyono. (2013). METODOLOGI PENELITIAN PENDIDIKAN. Yogyakarta: Penerbit Ombak.

UU RI No. 20 Tahun 2003 pasal 1 ayat 4. (2003). Retrieved from http://hukum.unsrat.ac.id/uu/uu_20_03.htm 